\title{
LA DIMENSIÓN EPISTÉMICA DE LA IMAGEN
} APORTES A LA ENSEÑANZA UNIVERSITARIA DE LAS ARTES

\section{EPISTEMIC DIMENSION OF IMAGE CONTRIBUTIONS TO TEACHING ART AT UNIVERSITY}

PaOLA SABRINA BelÉN / pbelen@fba.unlp.edu.ar

Instituto de Investigación en Enseñanza y Producción del Arte Argentino y Latinoamericano.

Facultad de Artes. Universidad Nacional de La Plata. Argentina

Recibido 8/2/2020 | Aceptado 19/4/2020

\section{RESUMEN}

La investigación propuesta busca dar cuenta de un estudio procesual que permitirá sistematizar la experiencia artística en el marco de una perspectiva acorde a las características propias del proceso artístico y de los paradigmas actuales del concepto de conocimiento. Se pretende, así, alcanzar un análisis de la dimensión epistémica de la imagen a partir de una selección temática de casos que posibilitarán indagar en imágenes de diferentes espacios y momentos históricos, las cuales no serán estudiadas cronológicamente sino a través de un enfoque complejo procesual, relacionaly situacional del arte, articulador además de los aportes de diversas disciplinas (Epistemología del arte, Estudios visuales, Historia del arte, Estética y Teoría del arte).

\section{PALABRAS CLAVE}

Arte; conocimiento; imagen

\section{ABSTRACT}

This research aims to make a processual study that will allow to systematize the artistic experience, in the context of perspective, according to the characteristics of artistic process and current paradigms of knowledge concept. The aim is to achieve an analysis of the epistemic dimension of the image from a thematic selection of cases, which will make it possible to examine images of different spaces and historical moments. These cases will not be studied chronologically but from a complex, processual, relational and situational approach to art, associated with contributions of different disciplines (Epistemology of Art, Visual Studies, History of Art, Aesthetics and Theory of Art).

\section{KEYWORDS}

Art; knowledge; image 


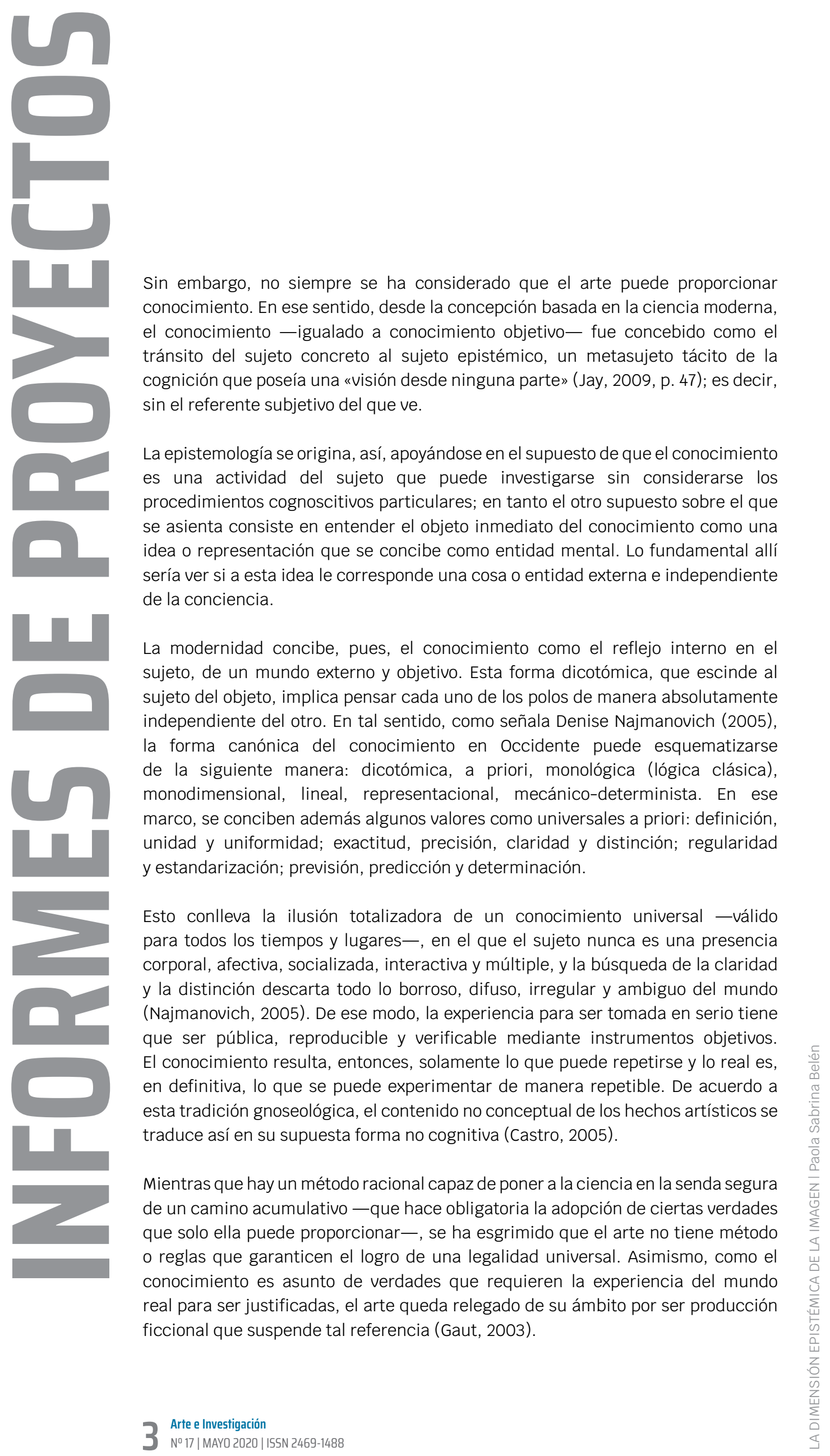




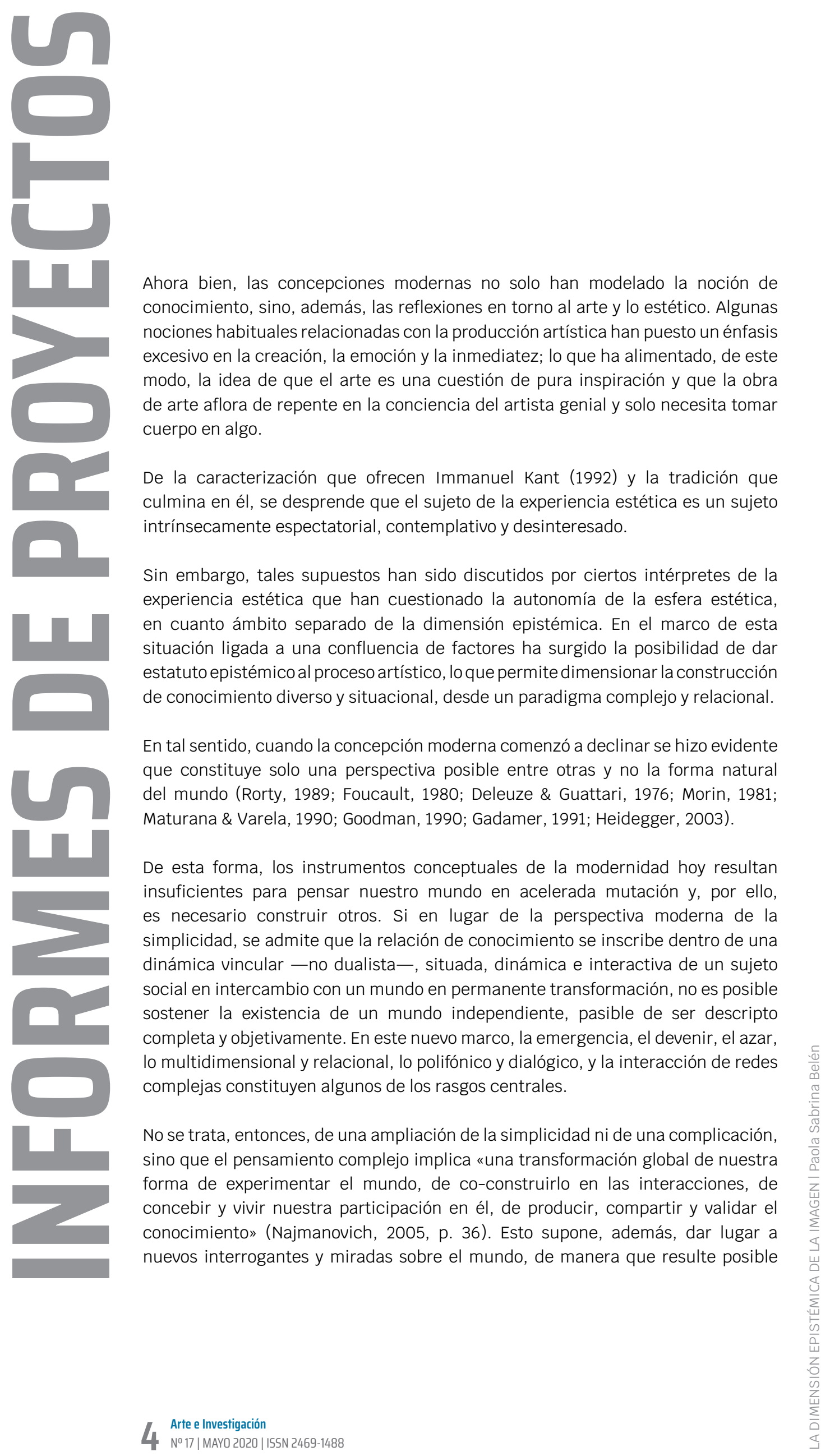




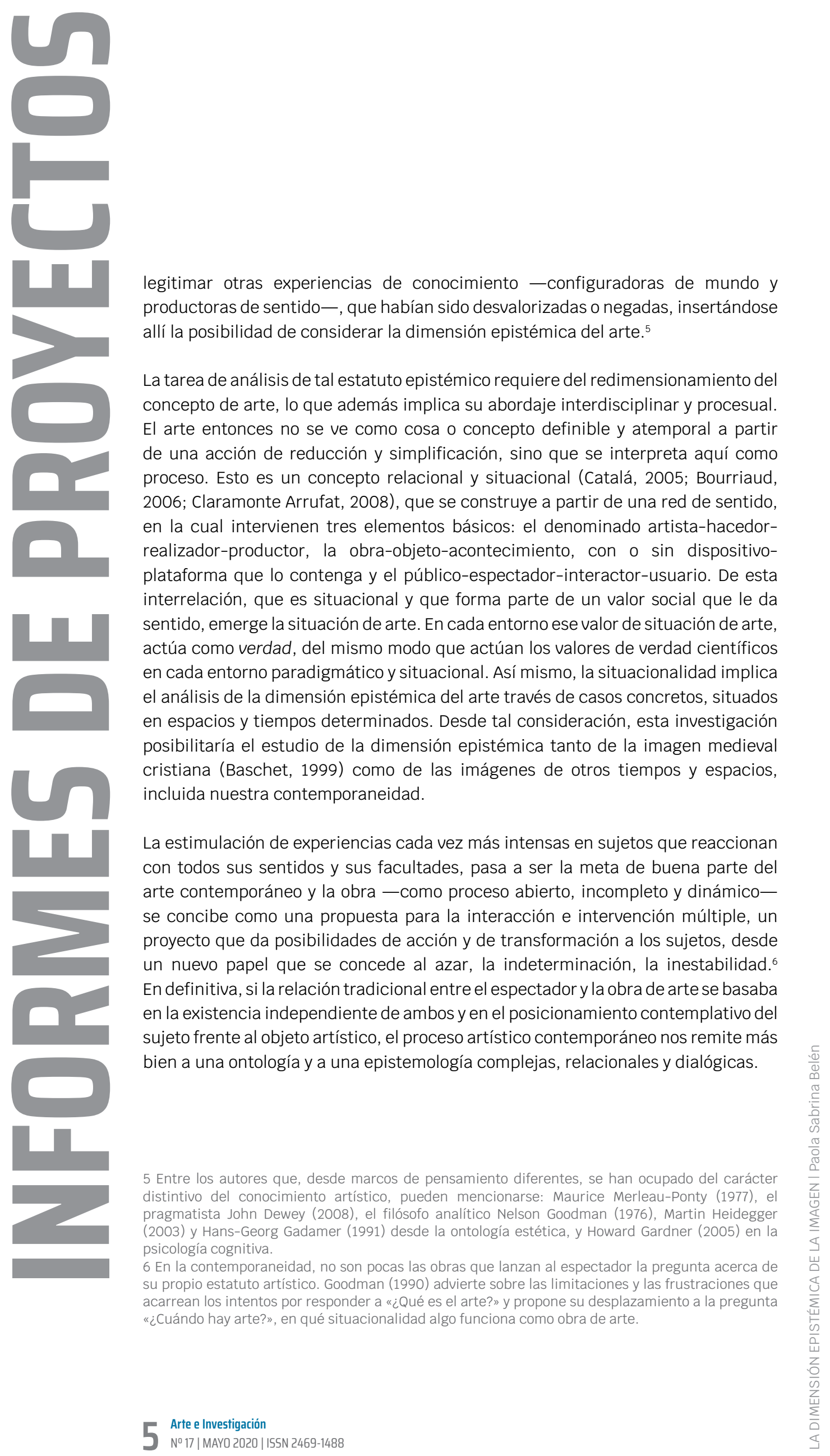




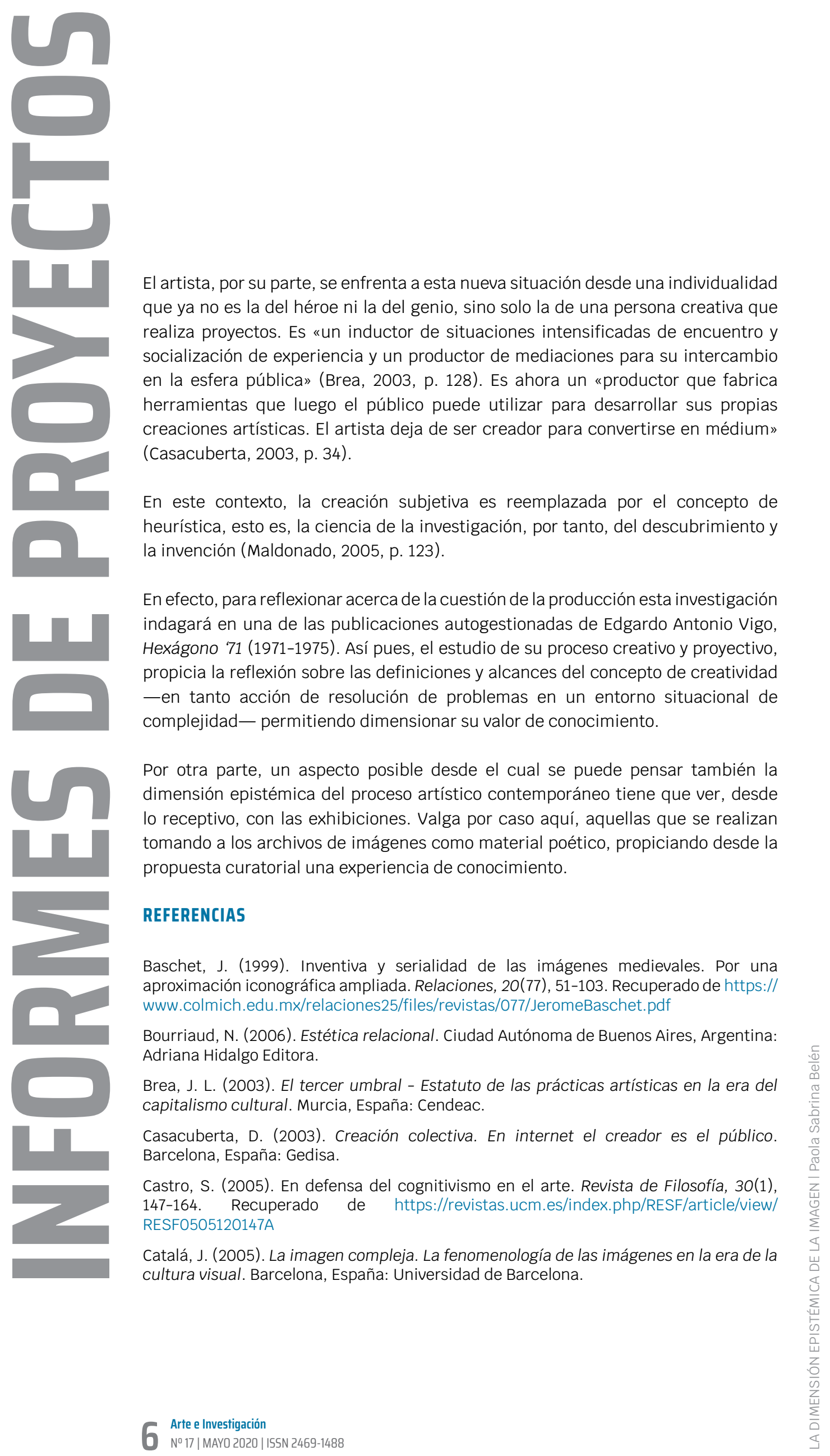


